\title{
Hakuin Ekaku's Insight into “The Deep Secret of Hen (Pian)-Sho (Zheng) Reciprocity" and His Koan "The Sound of a Single Hand"
}

\section{Gishin ToKIWA}

1. Hakuin Ekaku (1685-1768), a Rinzai-Zen master. lived in the middle of the Yedo Period. In one of his sermons in kana syllabary, Neboke-noMezame ("The Dozer Awakes") (1749), Hakuin, then sixty-five years old, for the first time announced his adoption of a new koan, "The Sound of A Single Hand," in place of the traditional "Jōshüs $M u$ " koan, as a device for Awakening practice, as follows :

Viewing contemporary Buddhists' ways of practice, we notice most of them so worldly-minded as to make the pursuit of fame and gain their principles; to help others in the affairs of money and land; some bonzes of low gift go so far as to misconduct themselves in a manner worse than some lay people. The Buddha Dharma is at a low ebb; Sákyamuni's original intent is far from being at work. The old-fellow-in-Hara's "The Sound of A Single Hand," Bodhidharma's nine years' wall-contemplation, Mahākāśyapa's smile in response to Śākyamuni's holding up a flower-things like these are the last things they think of. No wonder they throw all these things into the western sea, curry favor with lay parishioners, and make it their single concern to pass through this world. Even if they happen to see Buddhist scriptures or Zen masters' recorded sayings, they know nothing of their meaning. (HAKUIN OSHO ZENSHU 6, p, 292)

Hakuin celebrated pulication of this article by adding a peculiar postscript to it, as follows:

This is the day when "There is Only One Vehicle," the month when the "Moon of True Suchness" is in fullness, the first year of "Perfect Harmony that is Free from Form." In this country this is Sākyamuni's birthday, the fourth 
month of the year of hinoto (Chin., ding)-uma (wu) (A.D. 1749), Kan' en the second year.

Written by Kūgebō (Sky-Flower Ward) Nyūdō (Lay Practitioner), disciple of Mugen-in (Dream-Mirage Temple) Denkō Chōro (Lightening-Morning=Dew), who is the presiding priest of the Shohō-Jissō (All-Forms-are-Real-Forms-intheir-being-Formless) Temple, Daiye-Byōdō (Great-Discernment-of-Equality) Zan (Mountain), Jakumetsu (Calm-Extinction) Village, Fukashigi (Unthinkable) County, Mushō (No-Birth) State, Riji-Muge (Principle-and-Fact Uninterrupted) Dharma World.... (Ibid., pp. 298-9)

Hakuin, the true author, presented this article to the world with such a strange postscript, representing himself in the article as "the old-fellow-inHara." The kan-shi (Chin., gan-zhi, "Heavenly-Stem and Earthly-Branch") which he used for Kan'en the second year, hi-no-to uma (lit., "fire-horse"), does not exist in reality. The actual kan-shi of that year was tsuchi-no-to (ji) $m i$ (si), which literally means "soil-snake." No doubt Hakuin invented the set of hi-no-to-uma to express transformation of the image of the year of a snake in the underground into that of a heavenly horse rising high into the sky.

2. In this Neboke-no-Mezame Hakuin advocates hearing "The Sound of A Single Hand," and explains what it means, as follows :

By Kannon Bosatsu (Avalokitasvara Bodhisattva) is meant the contemplating (kan) of sounds (on), and that is what I mean by [hearing] the sound of a single hand. When you realize this, you get awakened. When you get awakened, the world over you see Kannon. (Jbid., pp. 294-5)

From Hakuin's explanation we know that hearing the sound of a single hand is made up of two moments: Avalokitasvara and Bodhisattva. One is the "contemplating of sounds" and the other the way of being in which one swears to get awakened together with others.

By the "contemplating of sounds" Hakuin means stopping them. By stopping all sounds he means realizing their source as our original way of being, that is, No-Sound. Hakuin illustrates this in the following paraphrase:

Your single hand will remain soundless unless you strike it against the other.

A single hand is not just soundless; it is No-Sound, the No-Sound that is Me. 


$$
\begin{aligned}
& \text { Hakuin Ekaku's Insight into "The Deep Secret of } \\
& \text { Hen (Pian)-Sho (Zheng) Reciprocity"... (G. TokIWA) }
\end{aligned}
$$

(Cf. Sekishu Onjō, H.O.Z. 4, 390-2 ; Yabukōji, H.O.Z. 5, 324-6)

In his comments on the Hekiganroku (Biyanlu), recorded in Hekigan-sh $\bar{u}$ Hishō (Tokyo 1916), from Case No. 23 through No. 100, Hakuin refers only to "The Sound of A Single Hand"; he never mentions the "Jōshü's $M u$ " koan there. Case No. 89 deals with the essential character of Kannon Bosatsu. Although he makes no reference to the koan there, the above-quoted passage of his own in the Neboke-no-Mezame makes us believe that this Case was the source of his new koan. Case No. 89 goes as follows:

Ungan (Yunyan) asked Dōgo (Daowu), "As for the Bodhisattva of Great Compassion, what does the bodhisattva do using so many hands and eyes?"

Dōgo said: "It's like groping for your pillow behind you in the middle of the night."

Ungan : "I understand."

Dōgo: "How do you understand?"

Ungan: "The entire body is hand and eye."

Dōgo: "Your remark goes quite well, but not to the full."

Ungan: "How would you say?"

Dōgo: "Hand and eye through and through."

(Hekigan-shü Hishö 9, pp. 799-800)

With Kannon the bodhisattva's hands are so many eyes, and vice versa. At the same time the bodhisttva is innumerable hands-eyes, and vice versa. What is seen-and touched-is the bodhisattva's own Self. The bodhisattva's hands and eyes are originally equal, and basically one. The hands-eyes as many as "one thousand" are the Buddha's Single Eye, which is none other than Hakuin's Single Hand. (Cf. one of Hakuin's comments on Case No. 65, Hekigan-shü Hishō, p. 616)

3. In his work in Chinese characters, Tōjō-Goi-Henshō-Kuketsu ("Tōzan Ryōkai's Five Ranks with Hen and Sho in Oral Transmission"), Hakuin takes up "Verses on the Five Ranks," by Master Tōzan Ryōkai (Dongshan Lianjie, 807-69), and gives his comments on each of them. (H.O.Z. 2, 85-8) In one later article in Chinese characters Hakuin identifies the second rank with "The Sound of A Single Hand," and qualifies the latter as the Wisdom of Equal Nature as well as the Samadhi (Self-Concentration) of Treasure Mi- 
Hakuin Ekaku's Insight into "The Deep Secret of

ror. (Hōkan-Ishō, H.O.Z. 1, 261-2; H.O.Z. 2, 86-7) In the Tōjō-Goi-HenshōKuketsu Hakuin makes these two qualities represent the second rank, Henchü-Shō (Pian-zhong-Zheng: "In the midst of the world of objectification or Discerning what is authentic or Emptiness is located"). (H.O.Z. 2, 86-7)

Hakuin's identification derives from the reason that hearing "The Sound of A Single Hand" implies the realization that one sees nothing external in others. According to Hakuin, the second of the Five Ranks, which represents the Wisdom of Equality, can include the first rank, Wisdom of the Great Mirror of Emptiness, on one hand. On the other hand it is on the way to the fifth, ultimate rank, through the third and fourth ranks. The third rank, according to Hakuin, represents Emptiness as the source of Discerning, and the latter is regarded as the functioning of the former. Reciprocity in this sense between Emptiness and Discerning is to work as the four Extensive Vows on Wisdom and Compassion. The fourth rank, with Hakuin, represents the Reciprocity being at work, in which work for others and work for oneself are one and the same thing. The fifth rank stands for the actualization of the fourth. The first, authentic rank, of Emptiness, according to Hakuin, tends to remain something negative and individualistic. Practitioners in this rank are likely to prove helpless in the world of commotion, noise, hatred and love, or discrimination. Hakuin considers this to be the reason why Master Tōzan had to set up the second rank. The disease into which practitioners in the first rank tend to fall should be removed through practice of the second rank. In fact the whole system of the Five Ranks keeps the "authentic" rank of Emptiness from remaining unauthentic; that is, it keeps practitioners from remaining helpless in the actualities of the world. To the contrary, it urges the first rank practitioner to find the way through ranks and ultimately to be settled in the fifth, "hearth of affliction," where two hands work as one, as is illustrated in the verse on Tokuun (Meghaśrī) and Zenzai (Sudhana), the two bodhisattvas who abided in oneness for seven days on a peak, a description in the Kegon-kyō Nyü-hokkai-bon (T.T. 10, p. 374a: Gandavyüha). Each of the first four ranks, according to Hakuin, is successively followed 
Hakuin Ekaku's Insight into "The Deep Secret of Hen (Pian)-Sho (Zheng) Reciprocity"... (G. TOKIWA)

by the next rank, so that practitioners in the respective rank can be relieved of the defects they would possibly suffer should they cling to it. Each of the ranks from the second on was "provisionally" set up, as Hakuin comments, by Master Tōzan. But let us ask of ourselves: Was it Master Tōzan who set up the ranks successively? No; rather it is the spontaneous movement within the five ranks; Hakuin named it Reciprocity (e-go: huihu) between the two moments: shō (zheng; "right" or "authentic"; "Emptiness") and hen (pian; "leaning to one side," "Discerning"), which urges practitioners at each rank to advance forward. This spontaneous, urging power may find its ultimate location in the fifth rank. Anyway, Hakuin was able to confirm his own method of practice through this system of the Five Ranks with its motivating power of Reciprocity. Hakuin discovered that:

The Five Ranks are the vessels that dash through the poison-mixed sea; the treasure-vehicle that breaks through the hard prison of the twofold emptiness [of self and the world]. (H.O.Z. 2, 82)

In the introduction of his view on the Five Ranks, Hakuin confesses that during his dhyana practice toward the end of the summer retreat (April 15 through July 15), Kan'en the first year, the secret of Hen-Sho Reciprocity suddenly shone forth, as if he were looking into his own palm; the rhinoceros of doubt died, and he could not help rejoicing. (H.O.Z. 2, 82-3) The name of the imperial era was officially changed that year from Enkyō to Kan'en on July 12th. The summer retreat ends on July 15th, so that Hakuin's experience must have taken place between July 12 and 15 . His publication of the Neboke-no-Mezame on April 8th, the next year (Kan'en the second) with the postscript partially quoted above, indicates that advocating his new koan, "The Sound of A Single Hand," was closely related to his insight into the Hen-Sho Reciprocity.

4. The title Neboke-no-Mezame suggests that Hakuin named it after Master Tōzan's verse on the second rank:

A wife, who has overslept, coming to an ancient mirror,

Distinctly sees her face there but not another "true" one.

Should she feel it lost to herself and begin searching for a shadow, 
There would be no way out.

(H.O.Z. 2, 86)

All this tells us that Hakuin's insight into the secret of Hen-Sho Reci= procity led him to invent the koan "The Sound of A Single Hand" in terms of the second rank. Hakuin seems to have decided to get practitioners to begin with the second rank, the rank of Hen-chu-Shō, i.e., Emptiness in Discerning, instead of with the first rank, Shō-chu-Hen, Discerning in Emptiness.

5. Our problem then is why Hakuin had to invent this new device.

It was already in his early article in Chinese characters, Sokkōroku Kaiyen Fusetsu (a lecture given in 1740, at the age of fifty-five) that Hakuin criticized those Zen practitioners who devoted themselves to the Nenbutsu practice. The same criticism appears in his article of 1749, Orategama the Fourth Letter (H. O.Z. 5) as well as in the two similar articles written in 1753, all in kana syllabary: Sekishu Onjō (H.O.Z. 4) and Yabukōji (H.O.Z. 5). It is worth considering the reason why there was such a strong tendency among Zen practitioners contemporary with and preceding Hakuin, to become Nenbutsu devotees. An apparently self-negating individualistic Zen-practice with Jōshu's Mu may not have satisfied their religious quest. The alleged calling-and-response between Amida Buddha and practisers through Nenbutsu may have had something to appeal to those Zen practitioners who were not satisfied with their practice. The Pure Land teaching was a new type of Buddhist religion based on the concept of contract, as it were, between God and man, insofar as seen from the side of man. There the Other Power, instead of Self, plays a central part.

But the Pure Land school is a branch of Buddhism, as far as the original vows of Amida Buddha are concerned. Amida Buddha is an Awakened one who benefits "others" by having them get free from otherness as well as from selfhood. This others-benefiting work can be fulfilled because Amida Buddha is free from selfhood and otherness. This means that insofar as otherness remains with Nenbutsu practisers, there will be no fulfillment of salvation or their birth in the Buddha's Pure Land. The calling- 
Hakuin Ekaku's Insight into "The Deep Secret of Hen (Pian)-Sho (Zheng) Reciprocity"... (G. TOKIWA)

and-response is a means through which Amida Buddha makes Nenbutsu practisers realize their true whereabouts, that is, Nirvana. When viewed from the side of Amida Buddha, the Pure Land teaching is a genuine branch fo bodhisattva Buddhism. This religion is based on the firm determination of Dharmākara Bodhisattva to establish a Pure Land through his all-embracing vow and the announcement of the eternal fulfillment of his vow, as Amida Buddha. Its unique point is that it emphasizes absolute reliance upon the saving power of Amida Buddha. There looms large the concept of grace and otherness. It is what a religion of apparently individualistic and negative nature lacks.

Now an authentic Awakening is free from selfhood and otherness as well as from being and nonbeing. Because of this original freedom the authentic Awakening can work equally as self and other, as well as as being and nonbeing. Hakuin's new device, "The Sound of A Single Hand," seems to have been invented with the purpose of having practitioners attain this kind of authentic Awakening. With a single hand every sound is stopped. Because of this ultimate ceasing of sound, the Single Hand can be where every sound, self and other, being and nonbeing, equally becomes its Self-functioning.

This seems to be why Hakuin invented the new koan through his criticism of those Zen practitioners who devoted themselves to Nenbutsu practice; they needed to get free from the concepts of selfhood and otherness as well as of being and nonbeing. The invention, certainly, coincided with his insight into the deep secret of the Five Ranks.

〈KEY WORDS〉 Nenbutsu and the Mu koan; Hakuin's koan: "The Sound of A Single Hand"; Hakuin's work, The Dozer Awakesi; Dongshan Lianjie's "Five Ranks"

(Professor, Hanazono University) 